\title{
Sex differences in the expression of lipid oxidation and glucose uptake genes in muscles of fasted mice
}

\author{
N.A. Feofanova ${ }^{1,2} \otimes$, T.V. Yakovleva ${ }^{2}$, E.N. Makarova ${ }^{2}$, N.M. Bazhan ${ }^{2}$ \\ ${ }^{1}$ Research Institute of Fundamental and Clinical Immunology, Novosibirsk, Russia \\ ${ }^{2}$ Institute of Cytology and Genetics, SB RAS, Novosibirsk, Russia \\ هe-mail: nataly.feofanova@gmail.com
}

Fasting has become increasingly popular for treatment and prevention of obesity. Sex differences in the mechanisms of adaptation to fasting may contribute to choosing a therapeutic strategy for correction of metabolic disorders. Hepatokine fibroblast growth factor 21 (FGF21) is involved in the adaptation to fasting. Muscles are assumed to be the main energy-consuming tissue in the body, as muscle metabolism plays an important role in the adaptation to nutritional deficit. However, there is still little information on sex differences in muscle and FGF21 physiological response to fasting. Our aim was to find out whether there were sex differences in hormonal regulation and the expression of genes controlling glucose and lipid metabolism in skeletal muscles in response to fasting. We estimated the effect of 24-hour fasting on the expression of genes involved in lipid (Ucp3, Cpt1) and carbohydrate (S/c2a4) metabolism in muscles and evaluated changes in body weight and blood plasma levels of glucose, insulin, free fatty acids (FFA), adiponectin, and FGF21 in male and female C57BL/6J mice. None of the genes studied (Ucp3, Cpt1 and S/c2a4) showed sex-related changes at mRNA levels in control groups, but females exposed to fasting demonstrated a significant increase in the expression of all genes as compared to control. Fasting significantly decreased body weight and glucose blood plasma levels in animals of both sexes but exerted no effect on the levels of insulin or FFA. The adiponectin and FGF21 levels were increased in response to fasting, the increase in females being significant. We were first to show sex dimorphism in muscle gene expression and FGF21 blood level in response to fasting. In females, the greater increase in FGF21 and adiponectin blood levels was positively associated with the greater upregulation of lipid oxidation and glucose uptake gene expression.

Key words: muscle; gene expression; fasting; metabolism; sex difference; mice; C57BL/6J strain.

For citation: Feofanova N.A., Yakovleva T.V., Makarova E.N., Bazhan N.M. Sex differences in the expression of lipid oxidation and glucose uptake genes in muscles of fasted mice. Vavilovskii Zhurnal Genetiki i Selektsii=Vavilov Journal of Genetics and Breeding. 2019;23(1):62-66. DOI 10.18699/VJ19.462

\section{Половые различия в экспрессии мышечных генов, вовлеченных в окисление липидов и захват глюкозы, у голодавших мышей}

\author{
Н.А. Феофанова ${ }^{1,2}$ 困, Т.В. Яковлева ${ }^{2}$, Е.Н. Макарова ${ }^{2}$, Н.М. Бажан ${ }^{2}$ \\ ${ }^{1}$ Научно-исследовательский институт фундаментальной и клинической иммунологии, Новосибирск, Россия \\ 2 Федеральный исследовательский центр Институт цитологии и генетики Сибирского отделения Российской академии наук, \\ Новосибирск, Россия \\ 凶e-mail: nataly.feofanova@gmail.com
}

\begin{abstract}
Голодание становится все более популярным средством для лечения и профилактики ожирения. Данные о половых различиях механизмов адаптации к голоданию могут быть актуальными при выборе терапевтической стратегии для коррекции нарушений обмена веществ. Гепатокин фактор роста фибробластов 21 (FGF21) вовлечен в регуляцию адаптации к голоданию. Основным потребителем энергии в организме является мышечная ткань, поэтому регуляция метаболизма мышц играет важную роль в ответе организма на пищевой дефицит. Однако половые особенности в физиологическом ответе FGF21 и мышечной ткани на голод пока еще недостаточно изучены. Целью данного исследования было изучение половых особенностей гормональных изменений в крови и экспрессии генов метаболизма глюкозы и жиров в скелетных мышцах в ответ на голод. Мы оценивали влияние 24-часового лишения пищи на экспрессию генов, участвующих в метаболизме липидов (Ucp3, Cpt1) и углеводов (S/c2a4) в мышцах, и изменения массы тела, уровня глюкозы, инсулина, свободных жирных кислот, адипонектина и FGF21 в крови у самцов и самок мышей C57BL/6J. У самцов и самок контрольных групп не выявлено половых различий в уровне мPHК генов Ucp3, Cpt1 и Slc2a4 в мышцах, под влиянием голода самки продемонстрировали значительное увеличение экспрессии всех генов по сравнению с контролем. Голодание достоверно снижало массу тела и уровень глюкозы в крови у животных обоих полов и не влияло на уровни инсулина и свободных жирных кислот в крови. Уровни адипонектина и FGF21 повышались в ответ на голодание, у самок это повышение было статистически достоверным. Мы впервые
\end{abstract}




\begin{abstract}
продемонстрировали половой диморфизм в экспрессии генов, вовлеченных в метаболизм липидов и углеводов (Ucp3, Cpt1 и Slc2a4) в мышцах, и уровне FGF21 в крови в ответ на голод: у самок происходит более выраженное повышение экспрессии генов, ассоциированное с ростом уровня FGF21 и адипонектина.
\end{abstract} Ключевые слова: мышцы; экспрессия генов; голод; метаболизм; половые различия; мыши; линия C57BL/6J.

\section{Introduction}

Nowadays, starvation is less challenging for the world population than hundreds of years ago; however, voluntary food deprivation is becoming increasingly popular, sometimes saving individuals from life-threatening obesity, sometimes being a symptom of mental disorders. Women are approximately threefold more vulnerable than men to psychiatric eating disorders and approximately twofold more vulnerable to severe and morbid obesity. They also appear to suffer more from these disorders in terms of physical and psychological functioning (Asarian, Geary, 2013). However, most animal studies have been made on males, whereas sex differences in the predisposition to metabolic disorders and mechanisms of physiological adaptation to fasting, in particular, are not understood.

Muscles are considered to be the main energy-consuming tissue in the body, and sex difference in muscle metabolism plays an important role in the adaptation to the shortage of energy substrates available during fasting (Thiebaud et al., 1982). Fasting increases the concentration of free fatty acids (FFA) in blood plasma and forces adaptive changes in the whole body and in skeletal muscle metabolism that enhance fat oxidation and reduce carbohydrate oxidation (Lundsgaard, Kiens, 2014). It is known that fasting increases the expression of genes implicated in the regulation of lipids as fuel substrate in skeletal muscles, such as the genes for uncoupling protein-3 (Ucp3), lipoprotein lipase, and muscle carnitine palmitoyltransferase I (Cpt1) (Hildebrandt, Neufer, 2000). There is an increasing body of evidence for a distinct sex dimorphism in the intrinsic properties of skeletal muscle, i. e., fiber type composition and capillarization, which is likely to affect the capacity for oxidative versus glycolytic energy turnover. Microarray data suggests that gender has a stronger influence on gene expression than age and training status in the human vastus lateralis muscle (Roth et al., 2002). Therefore, molecular mechanisms controlling muscle metabolism adaptation to fasting can be different in males and females.

Fibroblast growth factor 21 (FGF21) is one of the recently discovered factors induced in multiple organs in response to diverse nutrition stressors, such as fasting and amino acid deprivation, and it is assumed as a factor of adaptation to disturbances in energy homeostasis (Zhang et al., 2015). FGF21 can stimulate beta oxidation, induce thermogenesis, and enhance insulin sensitivity (Kharitonenkov, Adams, 2013). There is evidence from animal models (Zhang et al., 2012) and human studies (Foo et al., 2013) that physiologic effects of FGF21 in males and females differ. Interestingly, higher FGF21 expression and serum levels are observed in response to cafeteria diet in males than in females (Gasparin et al., 2018). However, there is still little data on sex difference in FGF21 involvement in the regulation of muscle metabolic response to fasting.

In this study, we consider changes of metabolic genes expression in muscle after 24-hour food deprivation in male and female C57BL/6J mice. The goal of this study was to investigate the sex-dependent regulation of genes related to fatty acid and carbohydrate metabolism (Ucp3, Cpt1 and Slc2a4) in muscle and its relationship with blood plasma levels of FGF21, free fatty acids, adiponectin, and insulin in response to fasting. Fasting-induced increase in expression of genes involved in FFA oxidation (Cpt1 and Ucp3) and glucose uptake (Slc2a4) was more pronounced in females than in males. In females, the predominant upregulation of genes related to glucose and lipid metabolism was positively associated with the predominant increase in FGF21 and adiponectin blood plasma levels.

\section{Materials and methods}

Ethical approval. All experiments were performed according to the European Convention for the Protection of Vertebrate Animals used for Experimental and other Scientific Purposes (Council of Europe No. 123, Strasbourg 1985) and Russian national instructions for the care and use of laboratory animals. The protocols were approved by the Independent Ethics Committee of the Institute of Cytology and Genetics (Siberian Branch of the Russian Academy of Sciences).

Animals. C57BL/6J mice were kept in the vivarium of the Institute of Cytology and Genetics. The mice were housed under a 12:12-h light-dark regime at an ambient temperature of $22{ }^{\circ} \mathrm{C}$. The mice were provided ad libitum access to commercial mouse chow (Assortiment Agro, Turakovo Village, Moscow oblast, Russia) and water.

To investigate the effects of food deprivation, 15-week old female and male mice were deprived of food at $9.00 \mathrm{am}$. Animals were killed by decapitation through $24 \mathrm{~h}$ of food deprivation. The mice from control groups were decapitated simultaneously with food-deprived mice. All mice were hosed individually during 3 weeks before experiment. Each experimental group included 7-10 animals.

Trunk blood samples were taken to measure FGF21, glucose, insulin, adiponectin, and free fatty acids concentrations, and samples of muscle tissue were taken to measure gene expression.

Plasma assays. Concentrations of FGF21 were measured with Rat/Mouse Fibroblast Growth Factor ELISA Kit, concentrations of insulin were measured with Rat/Mouse Insulin ELISA Kit, concentrations of adiponectin were measured with Mouse Adiponectin ELISA Kit (EMD Millipore Corporation, Billerica, MA, USA). Concentrations of glucose were measured with Fluitest GLU (Analyticon Biotechnologies AG, Germany). Concentrations of free fatty acids were measured with NEFA FS DiaSys (Diagnostic Systems GmbH, Germany).

Relative quantitation real-time PCR. Total RNA was isolated from tissue samples with ExtractRNA (Evrogen, Moscow, Russia) according to manufacturer's instructions. First-strand cDNA was synthesized with Moloney murine leukemia virus (MMLV) reverse transcriptase (Evrogen, Moscow, Russia) and oligo(dT) as a primer. Applied Biosystems 
TaqMan gene expression assays (Ucp3, Cpt1, Slc2a4) with $\beta$-actin as endogenous control (TaqMan endogenous controls with FAM dye label and MGB mouse $\beta$-actin (ACTB)) and qPCRmix-HS LowROX Master Mix (Evrogen, Moscow, Russia) were used for relative quantitation real-time PCR. Sequence amplification and fluorescence detection were done with the Applied Biosystems ViiA ${ }^{\text {TM }} 7$ Real-Time PCR System. Relative quantitation was performed by the comparative CT method, where CT is the threshold cycle.

Statistical analysis. The results are presented as means $\pm \mathrm{SE}$ from the indicated number of mice. Two-way ANOVA was used with factors "sex" (male, female) and "experimental group" (control, food deprivation) with multiple comparisons using the post hoc Fisher LSD test. Significance was determined as $p<0.05$. The STATISTICA 6 software package (StatSoft) was used for analysis.

\section{Results}

\section{Body weight and blood parameters}

Sex significantly affected body weight $(\mathrm{F}=208.8, p<0.001)$. Fasting induced a significant decrease in body weight $(\mathrm{F}=44.2, p<0.001)$. After 24-hour fasting, both males and females lost about $7 \%$ of body weight $(p<0.05)$ (Fig. $1, a)$.

Plasma glucose concentrations in fed mice did not differ between males and females from control groups. Fasting significantly decreased blood plasma glucose $(\mathrm{F}=21.7$, $p<0.01)$. Compared to the control group, plasma glucose levels significantly decreased in fasted animals of both sexes $(p<0.01)$ (see Fig. 1, $b$ ).

Sex and fasting did not affect plasma FFA or insulin concentrations (see Fig. 1, $c, d$ ). Both sex and fasting affected adiponectin blood plasma concentrations: they were significantly higher in females than in males $(\mathrm{F}=14.3, p<0.01)$, and in fasted mice higher than in control mice $(\mathrm{F}=4.96, p<0.05)$. In females, the fasting-induced increase in adiponectin levels was more pronounced than in males $(p<0.05)$ (see Fig. $1, e$ ).

Fasting significantly increased FGF21 blood plasma concentrations $(\mathrm{F}=4.5, p<0.05)$. In females, there was a significant difference between control and fasted groups $(p<0.05)$ (see Fig. 1, $f$ ).

\section{Expression of skeletal muscle energy metabolism genes}

For all genes (Ucp3, Cpt1 and Slc2a4) there were no sexrelated changes in basal muscle mRNA levels (Fig. 2). Fasting increased Ucp3 mRNA levels $(\mathrm{F}=4.64, p=0.04)$. The
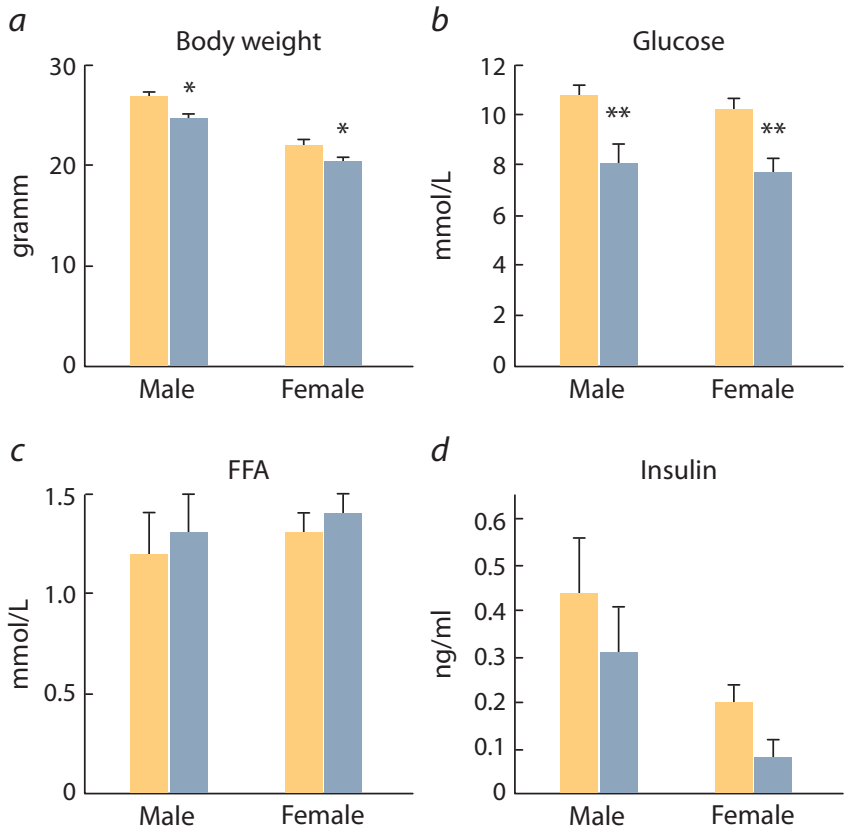

$d$
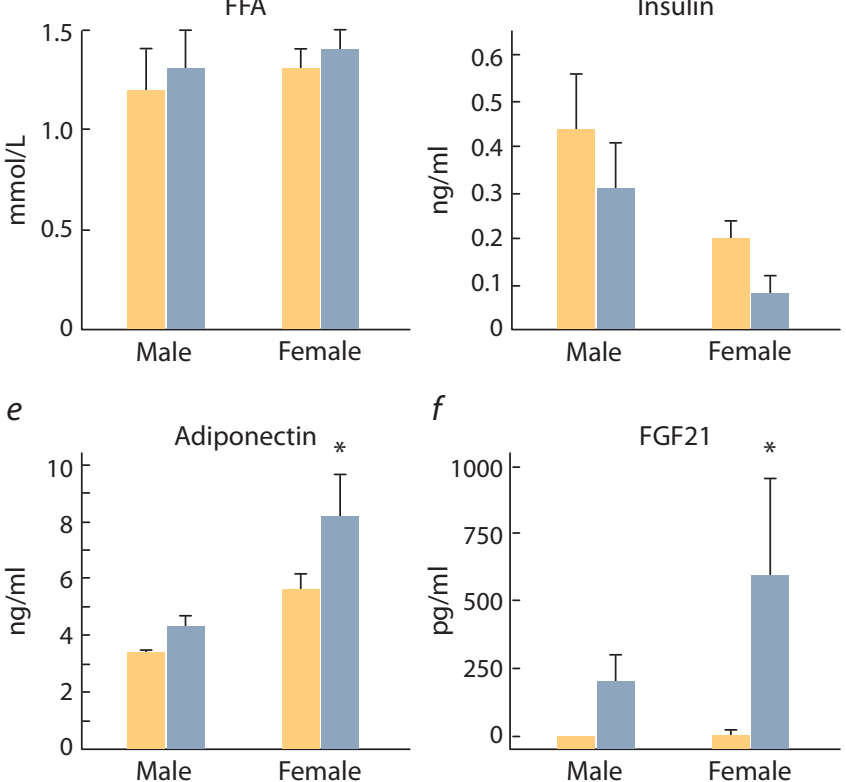

$f$

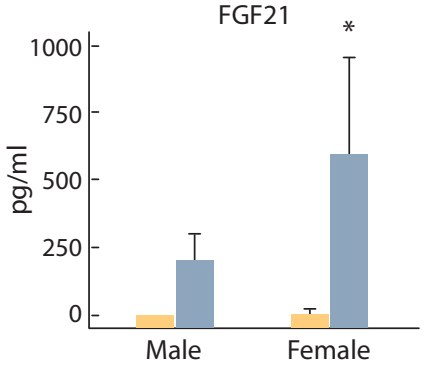

Fig. 1. Body weight, plasma glucose, free fatty acid, insulin, adiponectin, and FGF21 concentrations in control (white bars) and fasted (gray bars) C57BL/6J male and female mice.

Data are expressed as means \pm SEM. ${ }^{*} p<0.05,{ }^{* *} p<0.01$ versus control. Posthoc LSD Fisher.

fasting-induced increase of muscle Ucp3 mRNA was more pronounced in females $(p<0.01)$, while in males changes were not statistically significant (see Fig. 2,a). Cpt1 and Slc2a4 gene expression changed in females after fasting. Both Cpt1 and Slc2a 4 mRNA levels in fasted females were higher than in control females $(p<0.05)$ (see Fig. 2, $b, c)$. In males Cpt1 and Slc2a4 mRNA level changes in response to 24-hour food deprivation were statistically insignificant.
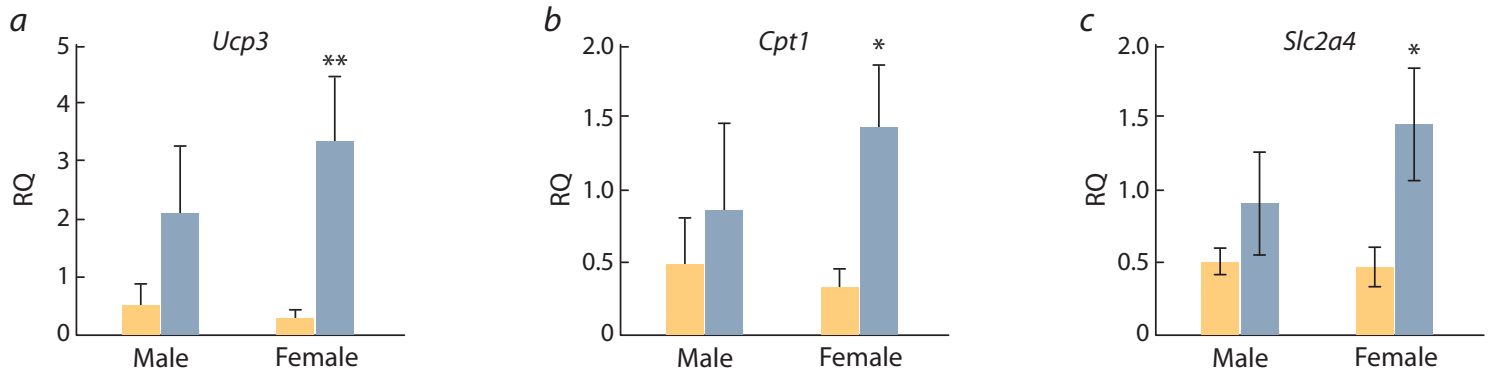

Fig. 2. Thigh muscle Ucp3, Cpt1, and S/c2a4 mRNA expression in control (white bars) and fasted (gray bars) male and female C57BL/6J mice.

Data are expressed as means \pm SEM. ${ }^{*} p<0.05,{ }^{* *} p<0.01$ versus control. Post-hoc LSD Fisher. 


\section{Discussion}

Our results regarding the expression of genes involved in the regulation of FFA oxidation ( $U c p 3, C p t 1)$ and glucose uptake (Slc2a4) in muscles demonstrate that the upregulation of these genes at the mRNA level in response to 24-h fasting is much more pronounced in females than in males.

Fasting glucose levels in plasma reflect the interplay between basal whole-body glucose disposal and endogenous glucose production. Blood plasma glucose responses to fasting in males and females were similar; they decreased significantly in both sexes. However, females demonstrated almost 3-fold higher increase in the muscle expression of glucose transporter Slc2a4, whereas the increase in males was not statistically significant. This finding suggests more intense glucose turnover in fasted females compared to fasted males.

Ucp3 expression level is assumed to be one of the main sensors of FFA in muscles, and it can be regulated by hormonal and dietary manipulations. Starvation increases muscle Ucp3 expression when fat stores are being rapidly mobilized (Samec et al., 1998a). FFAs act as an interorgan signal between fat stores and skeletal muscle tissue. It is of interest that circulating FFAs upregulate $U c p 3$ mRNA expression during starvation in slow-twitch (oxidative) muscles, such as the soleus muscle, but not in fast-twitch fibers (glycolytic/oxidative-glycolytic) muscles, which constitute the major fiber type of the total skeletal muscle mass (Samec et al., 1998b). We found no significant changes in the blood plasma FFA level in response to fasting in either males or females. There is evidence that Ucp3 expression changes are not always correlated with the blood FFA level. Some studies point to unchanged FFA levels and expression of key genes responsible for the uptake, transport, oxidation, and re-esterification of fatty acids during 10 to 40 -h fasting accompanied by a dramatic increase in Ucp3 gene expression in human skeletal muscles (Tunstall et al., 2002). A signal other than circulating FFAs must be implicated in the induction of $U c p 3$ expression. FGF21 is known to induce Ucp3 expression in cardiomyocytes in vitro (Planavila et al., 2015). As we found that blood plasma FGF21 levels were positively associated with the Ucp3 expression level, we suggest that FGF21 is involved in the upregulation of Ucp3 expression in skeletal muscles.

Several research teams have shown that the expression levels of genes related to the transport of fatty acids into the muscle are greater in women than in men. Skeletal muscles from women show higher expression levels of fatty acid transporter CD36, hormone-sensitive lipase and lipoprotein lipase (Lundsgaard, Kiens, 2014). Glycolytic capacity appears to be greater in men. Higher activities of glycogen phosphorylase, pyruvate kinase, phosphofructokinase, and lactate dehydrogenase have been demonstrated in muscles of young untrained men compared with women (Green et al., 1984). A greater capillary supply and a greater area percentage of type I fibers in women are likely to enhance nutritive flow and increase oxidative glucose and fatty acid metabolism, thereby contributing to gender differences in skeletal muscle metabolism and insulin sensitivity (Lundsgaard, Kiens, 2014). Our data are in good agreement with these facts. They suggest that the increased potential for beta-oxidation rather than for glycolysis is realized in female muscles under fasting conditions. It could be of adaptive significance, as females normally have a lesser skeletal muscle mass and greater adipose mass than men.

Blood plasma concentrations of adiponectin are positively associated with whole-body insulin sensitivity (Furler et al., 2006; Hojlund et al., 2006). In our study, adiponectin levels in both the control and fasted groups were significantly higher in females than in males, and they increased in females but not in males in response to fasting. This result is consistent with human studies (Lundsgaard, Kiens, 2014). Adiponectin promotes insulin sensitivity in skeletal muscles, increasing Glut4 (Slc2a4 product) translocation to plasma membrane and glucose uptake, and enhances fatty acid oxidation via AMPK-dependent mechanisms (Nicholson et al., 2018). FGF21 is known to directly stimulate adiponectin secretion in rodents, and adiponectin is required for FGF21 effects, as adiponectin-knockout mice are refractory to changes in energy expenditure evoked by FGF21 administration (Holland et al., 2013). We suggest that FGF21 is involved in the regulation of lipid metabolism gene expression in muscle via adiponectin stimulation.

In this study, we were first to show sex dimorphism in muscle gene expression and FGF21 blood levels in response to fasting. In females, more pronounced increase of FGF21 and adiponectin blood levels was positively associated with more pronounced upregulation of lipid oxidation and glucose intake gene expression.

\section{References}

Asarian L., Geary N. Sex differences in the physiology of eating. Am. J. Physiol. Regul. Integr. Comp. Physiol. 2013;305(11):1215-1267. DOI 10.1152/ajpregu.00446.2012.

Foo J.P., Aronis K.N., Chamberland J.P., Paruthi J., Moon H.S., Mantzoros C.S. Fibroblast growth factor 21 levels in young healthy females display day and night variations and are increased in response to short-term energy deprivation through a leptin-independent pathway. Diabetes Care. 2013;36(4):935-942. DOI 10.2337/dc12-0497.

Furler S.M., Gan S.K., Poynten A.M., Chisholm D.J., Campbell L.V., Kriketos A.D. Relationship of adiponectin with insulin sensitivity in humans, independent of lipid availability. Obesity (Silver Spring). 2006;14(2):228-234. DOI 10.1038/oby.2006.29.

Gasparin F.R.S., Carreño F.O., Mewes J.M., Gilglioni E.H., Pagadigorria C.L.S., Natali M.R.M., Utsunomiya K.S., Constantin R.P., Ouchida A.T., Curti C., Gaemers I.C., Elferink R.P.J.O., Constantin J., Ishii-Iwamoto E.L. Sex differences in the development of hepatic steatosis in cafeteria diet-induced obesity in young mice. Biochim. Biophys. Acta. Mol. Basis. Dis. 2018;1864(7):2495-2509. DOI 10.1016/j.bbadis.2018.04.004.

Green H.J., Fraser I.G., Ranney D.A. Male and female differences in enzyme activities of energy metabolism in vastus lateralis muscle. J. Neurol. Sci. 1984;65(3):323-331.

Hildebrandt A.L., Neufer P.D. Exercise attenuates the fasting-induced transcriptional activation of metabolic genes in skeletal muscle. Am. J. Physiol. Endocrinol. Metab. 2000;278(6):1078-1086. DOI 10.1152/ajpendo.2000.278.6.E1078.

Hojlund K., Frystyk J., Levin K., Flyvbjerg A., Wojtaszewski J.F., Beck-Nielsen H. Reduced plasma adiponectin concentrations may contribute to impaired insulin activation of glycogen synthase in skeletal muscle of patients with type 2 diabetes. Diabetologia. 2006; 49(6):1283-1291. DOI 10.1007/s00125-006-0240-5.

Holland W.L., Adams A.C., Brozinick J.T., Bui H.H., Miyauchi Y., Kusminski C.M., Bauer S.M., Wade M., Singhal E., Cheng C.C., Volk K., Kuo M.S., Gordillo R., Kharitonenkov A., Scherer P.E. An FGF21-adiponectin-ceramide axis controls energy expenditure and insulin action in mice. Cell. Metab. 2013;7(5):790-797. DOI 10.1016/j.cmet.2013.03.019. 
Kharitonenkov A., Adams A.C. Inventing new medicines: The FGF21 story. Mol. Metab. 2013;3(3):221-229. DOI 10.1016/j.molmet.2013. 12.003.

Lundsgaard A.M., Kiens B. Gender differences in skeletal muscle substrate metabolism - molecular mechanisms and insulin sensitivity. Front. Endocrinol. (Lausanne). 2014;135:195. DOI 10.3389/ fendo.2014.00195.

Nicholson T., Church C., Baker D.J., Jones S.W. The role of adipokines in skeletal muscle inflammation and insulin sensitivity. J. Inflamm. (Lond). 2018;15:9. DOI 10.1186/s12950-018-0185-8.

Planavila A., Redondo-Angulo I., Ribas F., Garrabou G., Casademont J., Giralt M., Villarroya F. Fibroblast growth factor 21 protects the heart from oxidative stress. Cardiovasc. Res. 2015;106(1):19-31. DOI $10.1093 / \mathrm{cvr} / \mathrm{cvu} 263$.

Roth S.M., Ferrell R.E., Peters D.G., Metter E.J., Hurley B.F., Rogers M.A. Influence of age, sex, and strength training on human muscle gene expression determined by microarray. Physiol. Genomics. 2002;10(3):181-190. DOI 10.1152/physiolgenomics.00028.2002.

Samec S., Seydoux J., Dulloo A.G. Role of UCP homologues in skeletal muscles and brown adipose tissue: mediators of thermogenesis or regulators of lipids as fuel substrate? FASEB J. 1998a;12(9): 715-724.
Samec S., Seydoux J., Dulloo A.G. Interorgan signaling between adipose tissue metabolism and skeletal muscle uncoupling protein homologs: is there a role for circulating free fatty acids? Diabetes. 1998b;47(11):1693-1698.

Thiebaud D., Jacot E., DeFronzo R.A., Maeder E., Jequier E., Felber J.P. The effect of graded doses of insulin on total glucose uptake, glucose oxidation, and glucose storage in man. Diabetes. 1982; 31(11):957-963.

Tunstall R.J., Mehan K.A., Hargreaves M., Spriet L.L., CameronSmith D. Fasting activates the gene expression of UCP3 independent of genes necessary for lipid transport and oxidation in skeletal muscle. Biochem. Biophys. Res. Commun. 2002;294(2):301-308. DOI 10.1016/S0006-291X(02)00473-4.

Zhang F., Yu L., Lin X., Cheng P., He L., Li X., Lu X., Tan Y., Yang H., Cai L., Zhang C. Minireview: Roles of fibroblast growth factors 19 and 21 in metabolic regulation and chronic diseases. Mol. Endocrinol. 2015;29(10):1400-1413. DOI 10.1210/me.2015-1155.

Zhang Y., Xie Y., Berglund E.D., Coate K.C., He T.T., Katafuchi T., Xiao G., Potthoff M.J., Wei W., Wan Y., Yu R.T., Evans R.M., Kliewer S.A., Mangelsdorf D.J. The starvation hormone, fibroblast growth factor-21, extends lifespan in mice. Elife. 2012;1:e0065. DOI 10.7554/eLife.00065.

\section{ORCID ID}

N.A. Feofanova orcid.org/0000-0002-2591-1623

Acknowledgements. The study was supported by the Russian Science Foundation, project 17-15-01036. Use of the equipment of the Center for Genetic Resources of Laboratory Animals at ICG SB RAS was supported by the Ministry of Education and Science of Russia (unique project identifier RFMEFI62117X0015)

Conflict of interest. The authors declare no conflict of interest.

Received November 6, 2018. Revised December 13, 2018. Accepted December 13, 2018. 